\title{
Methyl beta-carboline-3-carboxylate reverses the working memory deficits induced either by chronic alcohol consumption or mammillary body lesions in BALB/c mice
}

\author{
D. BÉRACOCHÉA \\ University of Bordeaux I, Talence, France \\ A. KRAZEM \\ University of Tizi-Ouzou, Tizi-Ouzou, Algeria \\ and \\ R. JAFFARD \\ University of Bordeaux I, Talence, France
}

\begin{abstract}
This study showed that both chronic ethanol consumption and mammillary body (MB) lesions induced a trial-dependent sequential alternation deficit together with a reduction of anxiety-like reactions in an elevated plus maze and in an open field. The administration of $\beta-C C M(0.5 \mathrm{mg} / \mathrm{kg}, \mathrm{s.c}$. $)$ increased anxiety-like reactions in all groups but significantly improved spontaneous alternation rates only in the alcohol group. However, increasing the dose of $\beta$-CCM from 0.5 to $1.0 \mathrm{mg} / \mathrm{kg}$ also produced a memory-enhancing effect in MB-lesioned subjects. Taken together, this study shows that (1) memory deficits induced by chronic ethanol administration and MB lesions are reversed by $\beta$-CCM administration and that (2) given the dose effects in MB mice, the MB could mediate, at least in part, the memory-enhancing effects of the drug.
\end{abstract}

The mammillary bodies (MBs) of the hypothalamus play a significant role in emotional behavior and have been proposed as a major site for the antianxiety actions of benzodiazepine (BDZ) in the brain (Kataoka, Shibata, Gomita, \& Ueki, 1982). This concept has gained recent support from a study showing that, in the human brain, particularly high densities of BDZ binding sites are observed in the mammillary bodies as well as in the hippocampus and the anterior and posterior cingulate cortical areas (Eymin, Koll, \& Laurent, 1992). In parallel to the possible involvement of the MBs in emotion, the mammillo-cingular pathway also plays a role in memory processes. For example, the amnesia resulting from chronic alcohol consumption in Korsakoff's syndrome is due, at least in part, to damage of the mammillo-thalamiccingular pathway (Lhermitte \& Signoret, 1972).

Animal models of Korsakoff syndrome have also demonstrated a relation between damage to the mammillothalamic-cingular pathway and memory dysfunction. For example, we previously showed that chronic ethanol con-

This research was supported by the CNRS (URA 339). The authors thank G. Chapouthier and R. H. Dodd for their collaboration and helpful advice, and Thomas Durkin for his help with the English in the writing of this paper. Correspondence should be addressed to D. Béracochéa, Laboratoire de Neurosciences Cognitives et Comportementales, URA CNRS 339, Université de Bordeaux I, UFR de Biologie Animale, Avenue des Facultés, 33405 Talence Cedex, France. sumption produced restricted but significant cell loss in the MBs of mice, whereas it only moderately damaged other brain areas (Béracochéa, Lescaudron, Tako, Verna, \& Jaffard, 1987; Lescaudron, Béracochéa, Verna, \& Jaffard, 1984). More importantly, both chronic ethanol administration or MB lesions in normal mice produced similar and selective impairments of memory retrieval processes (Béracochéa \& Jaffard, 1985, 1987; Béracochéa et al., 1987). These findings suggest that damage to the MBs is of critical importance in the production of memory impairments resulting from chronic alcohol consumption. In addition to the memory dysfunction, emotional disorders were also observed following both MB lesions and chronic ethanol consumption. Indeed, these two treatments reduced anxiogenic-like reactions in an elevated plus maze and in an open-field task (Béracochéa, 1992; Béracochéa \& Krazem, 1991).

Given the simultaneous presence of both memory impairments and emotional disorders in experimental mice, one could postulate a possible link between the apparent "hypoanxiety" induced by the treatments and the associated memory pathology. Thus, if hypoanxiety of experimental subjects was responsible for the memory deficits, it follows that a compound known to increase anxiety should attenuate the memory impairments of experimental mice.

Methyl beta-carboline-3-carboxylate $(\beta-\mathrm{CCM})$ is a benzodiazepine inverse agonist acting at the GABA/BZD 
receptor complex (Hunkeler et al., 1981) and decreasing $\mathrm{GABA}_{\mathrm{A}}$ receptor affinity. $\beta-\mathrm{CCM}$ has been reported to induce anxiogenic-like reactions and to improve memory in various tasks in normal subjects of several species (Chapouthier, Rafalli-Sebille, Venault, Simiand, \& Dodd, 1991; McNamara \& Skelton, 1993; Venault et al., 1986). In the present study, $\beta$-CCM was administered in experimental subjects and their respective controls, and the effects of the drug on tests inducing anxiogenic-like reactions and on working memory performance were determined.

\section{METHOD}

\section{Animals}

The study was conducted using male mice of the Balb/c strain received at 6 weeks of age from Iffa-Credo, Lyon, France. On arrival, the mice were housed collectively in colony cages $(40 \mathrm{~cm}$ long $\times 25 \mathrm{~cm}$ high $\times 20 \mathrm{~cm}$ wide; $n=20$ subjects per cage), matched for weight, and placed in an animal room (ambient temperature $=22^{\circ} \mathrm{C}$; automatic light cycle, $0800-2000 \mathrm{~h}$ ) with free access to food and water. They remained in collective cages until the age of 12 weeks.

\section{Alcohol Administration}

The 12-week-old mice were again housed in collective cages, with 10 subjects per cage. They were offered as their sole source of liquid increasing concentrated solutions of ethanol as follows: $4 \%(\mathrm{v} / \mathrm{v})$ the first week, $8 \%(\mathrm{v} / \mathrm{v})$ the second week, and $12 \%(\mathrm{v} / \mathrm{v})$ during the following 11 consecutive months. The solutions were mixed from $95 \%$ ethanol and supplemented with saccharose ( $30 \mathrm{~g} /$ liter). The solutions were freely available to the subjects in two $250-\mathrm{ml}$ bottles. Dry food was also freely available throughout the experiment (Extra-Labo, Pietrement, France). The subjects remained in collective cages during the alcohol-administration period. Mice of the first control group were pair-fed with an isocaloric solution of dextrimaltose and dry food. Mice of the second control group had ad-lib access to dry food and water. Twice weekly, the subjects were weighed and the quantities of food and ethanol and dextrimaltose solutions consumed were measured. At the same time, the animals were placed into clean cages with fresh ethanol and dextrimaltose solutions. In all experiments, mice of the alcohol and pair-fed groups were progressively withdrawn (i.e., replaced on access to water only) at least 4 weeks before behavioral testing began. All animals were then housed in individual cages, with free access to food and water.

\section{Surgery}

Animals assigned to the MB group were operated as follows: the mice were deeply anesthetized (sodium pentobarbital, i.p., $100 \mathrm{mg} / \mathrm{kg}$ ) and placed on a stereotaxic apparatus (Kopf instrument) with the incisor bar level with the interaural line. The distance between the incisor bar and the interaural line was $1.6 \mathrm{~cm}$. Lesions were made at the following coordinates: anteroposterior, $2.5 \mathrm{~mm}$ posterior to the bregma; midline vertical, $5.3 \mathrm{~mm}$ below the skull. A small amount $(0.30 \mu \mathrm{l})$ of an ibotenic acid solution $(10 \mu \mathrm{g} / \mu \mathrm{l})$ was injected in situ via a glass pipette fixed by glue to a $1-\mu 1$ Hamilton syringe. Mice of the sham group were operated according to the same procedure used for lesioned animals; however, the glass pipette was lowered into the MB, but no solution was injected. Following behavioral testing, the animals were administered a lethal dose of pentobarbital and rapidly perfused with physiological saline, followed by $10 \%$ formalin (Ismatec Instrument pump). Brains were removed, soaked in a $20 \%$ formalin solution for 10 days, and processed for histological analyses. Brains were cut in the coronal plane and sections ( $40 \mu \mathrm{m}$ thick) were then stained with cresyl violet.

\section{Drugs}

$\beta$-CCM (a generous gift from R. H. Dodd) was synthesized at the Institut de Chimie des Substances Naturelles (Gif-sur-Yvette, France). This compound was initially dissolved in $0.1-\mathrm{N} \mathrm{HCl}$ and then diluted to final concentration with saline.

\section{Tests of Emotionality}

Elevated plus maze. Measures of the emotional consequences of the treatments were assessed in the open field and the elevated plus maze tasks. These two tasks are widely used to measure anxietylike reactions in various pharmacological studies using rodents as subjects (Dennenberg, 1969; File \& Baldwin, 1987; Lister, 1987; Pellow, Chopin, File, \& Briley, 1985). The choice of these tasks was also due to the fact that they enable measures of the modification of exploratory patterns in an anxiogenic situation and that they do not involve food deprivation and reward, as was the case in the memory task used in the present study. Indeed, it has been shown that both hyperphagic and anorectic effects can be generated by actions of selected ligands at $\mathrm{BDZ}$ receptors (Cooper, 1987); these effects on food consumption may interfere with measures of both the emotional reactivity and memory performances in rewarded situations.

The plus maze, which was constructed of grey Plexiglas, consisted of four arms arranged in the shape of a plus sign. Each arm was $30 \mathrm{~cm}$ long, $7 \mathrm{~cm}$ wide, and was elevated $40 \mathrm{~cm}$ above the ground. The four arms were joined at the center by a $7-\mathrm{cm}$ square platform. Two opposite arms of the plus maze were enclosed by sidewalls $17 \mathrm{~cm}$ high, but open on the top; the remaining arms did not have sidewalls. These walls did not extend from the center of the maze. At the beginning of each test, the mice were placed on the center of the maze in a cylinder $(8 \mathrm{~cm}$ diameter, $17 \mathrm{~cm}$ high) for $30 \mathrm{sec}$. The cylinder was then removed, and the mice were allowed to freely explore all arms of the maze for $10 \mathrm{~min}$. Activity and latencies were measured by the experimenters using semiautomatic counters and timers. An entry was counted only when a mouse entered an arm with all four paws. Two measures of anxiety were taken. The first was the ratio of the time spent in the open arms divided by the total time spent in all arms of the maze (time ratio). The second was the ratio of entries into the open arms divided by the total number of entries in all arms (entries ratio). As operationally defined, the smaller are these ratios, the more anxious is the mouse.

Open field. The open-field chamber was constructed of wood in the shape of a square measuring $120 \mathrm{~cm}$ per side. The floor was painted white and divided into 64 squares by black lines drawn on the floor. Illumination was provided by two lamps positioned $2 \mathrm{~m}$ above the apparatus and providing a 600 -lux illumination equally distributed over the whole surface of the apparatus. At the start of each trial, the animals were placed on the center of the apparatus in a small cylinder. Following a 30 -sec delay, the cylinder was removed, and the subjects were allowed to freely explore the apparatus for $10 \mathrm{~min}$. Two measures were taken: (1) the total number of squares crossed by the subjects (an index of activity) and (2) the number of fecal boli recovered after the 10 -min period (an index of emotionality).

\section{Test of Memory}

Spontaneous alternation. Spontaneous alternation (SA) is the innate tendency of rodents to alternate on each trial, over a series of successive runs (sequential procedure) in a T-maze, the choice of the visited goal arm. The sequential procedure enables the experimenter to distinguish between the rodent's ability to alternate per se (second trials of a series) from its progressive inability to do so as the number of trials increased. In this latter case, repetitive testing (i.e., sequences of more than two trials) constitutes a potent source of proactive interference since the response on trial $N$ (which depends on information received on trial $N-1$ ) may be influenced by all previous information received from trials 1 to $N-2$ (Grant, 
1981; Roberts \& Dalc, 1981). Accordingly, this task involves a working memory component, since correct choices require the subject to refer to specific information that varies from trial to trial (Béracochéa \& Jaffard, 1985, 1987, 1990; O’Keefe, 1979).

In the present study, the task was performed in a T-maze constructed of gray Plexiglas $(30 \mathrm{~cm}$ long, $10 \mathrm{~cm}$ wide, and $25 \mathrm{~cm}$ high). All subjects were submitted to daily sessions of six successive trials separated by a 30 -sec intertrial interval (ITI). To begin a trial, the subjects were placed in the startbox $(10 \times 12 \mathrm{~cm})$ for $30 \mathrm{sec}$. Once this time had elapsed, the door to the stem was opened. When the mouse entered one of the arms, the door to that arm was closed. The mouse remained in the goal arm for $30 \mathrm{sec}$. Once this time had elapsed, it was subsequently removed and placed into the startbox for a new trial.

\section{General Procedure}

Independent groups of mice were injected with either saline (s.c.) or $\beta$-CCM $(0.5 \mathrm{mg} / \mathrm{kg}$ and $1.0 \mathrm{mg} / \mathrm{kg})$. The mice were submitted to behavioral testing $20 \mathrm{~min}$ after drug administration. All subjects were first submitted to the open field, then to the elevated plus maze followed by the SA task. The choice of this task sequence was based on a preliminary study using nontreated mice. According to these findings, performances in the open field and the elevated plus maze were not sensitive to the position of the tasks in the sequence; in contrast, more stable between-subject performances were observed in the alternation task when this task was placed at the end rather than at the beginning of the series.

The three tasks were run within a single time period of $40 \mathrm{~min}$. The open field, elevated plus maze, and SA tasks were conducted in different rooms. Each mouse was tested once for each task. The animals were not food-deprived during the experiments. Two days before being submitted to behavioral testing and drug administration, the animals were given two free exploration sessions of the T-maze (one daily session) of 10 min each, in order to familiarize each subject with the apparatus and the context of the maze.

The study was conducted on 130 mice divided into eight groups as follows: controls, $n=28 ; \beta-\mathrm{CCM}(0.5 \mathrm{mg} / \mathrm{kg}), n=14 ; \beta-\mathrm{CCM}$ $(1.0 \mathrm{mg} / \mathrm{kg}), n=21$; alcohol-saline, $n=10$; alcohol- $\beta$-CCM $(0.5 \mathrm{mg} / \mathrm{kg}), n=11 ; \mathrm{MB}-\mathrm{saline}, n=9 ; \mathrm{MB}-\beta-\mathrm{CCM}(0.5 \mathrm{mg} / \mathrm{kg})$, $n=18 ; \mathrm{MB}-\beta-\mathrm{CCM}(1.0 \mathrm{mg} / \mathrm{kg}), n=19$.

\section{Statistical Analysis}

Statistical analysis was carried out on transformed data (arcsin) followed by post hoc factorial or repeated measures analyses of variance (ANOVAs). Since a global ANOVA showed no statistical significant differences between the different control groups of this study (normal mice, saline-treated mice, sham-operated salinetreated mice, and pair-fed saline-treated subjects; $p>.05$, in all comparisons) on memory and the open-field and elevated plus maze tasks, these groups were pooled (control group) for further statistical comparisons with experimental subjects.

\section{RESULTS}

\section{Histological Analysis}

Lesions were mainly located in the posterior and medial parts of the median mammillary nucleus, whereas moderate damage was also observed in adjacent lateral nuclei (both sides). No obvious damage was observed in the supramammillary area (see Figure 1).

\section{Tests of Emotionality}

Open field: Locomotor activity. Data are summarized in Table 1. A two-factor ANOVA showed that changes in locomotor activity following administration of $\beta$-CCM
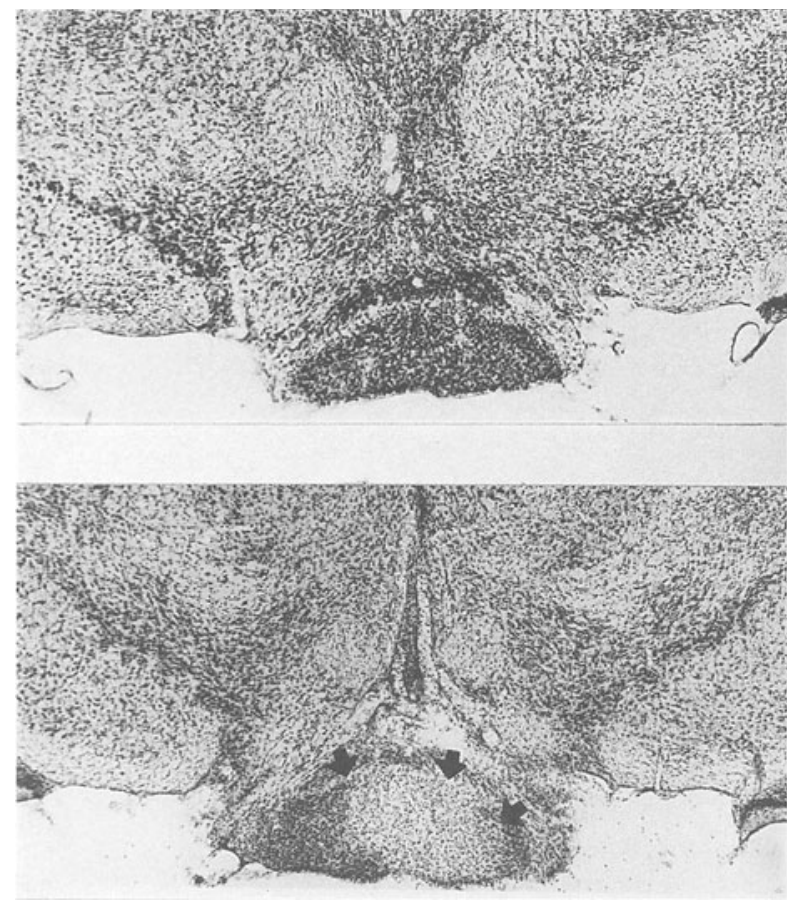

Figure 1. Photographic illustrations of the ibotenic acid lesion of the mammillary bodies (bottom) relative to a control (top).

at $0.5 \mathrm{mg} / \mathrm{kg}$ was significantly different among the groups $[F(2,84)=3.19, p<.05]$. Irrespective of the groups, $\beta$-CCM produced an overall significant decrease in locomotor activity [treatment, $F(1,84)=28.5, p<$ $.001]$; however, the magnitude of this reduction was significantly more pronounced in the alcohol group than in controls $[F(1,59)=4.53, p<.05]$. A similar, although nonsignificant, tendency was also observed in the MBlesioned group $[F(1,65)=3.48 ; p=.06]$. One must observe, however, that this differential effect came both from a nonsignificant increase in locomotor activity in $\mathrm{MB}$ and alcohol groups treated with saline [vs. control, $F(2,44)=$ $1.83, p=.17]$ together with an inverse pattern of differences under $\beta$-CCM $[F(2,40)=2.33, p=.12]$ (see Table 1). (It is interesting to note, for future comparisons of SA behavior, increasing the dose of $\beta$-CCM from $0.5 \mathrm{mg} / \mathrm{kg}$ to $1.0 \mathrm{mg} / \mathrm{kg}$ did not produce any further decrease in locomotor activity in MB-lesioned mice.)

Open field: Defecation. A two-factor ANOVA showed that $\beta$-CCM administration at $0.5 \mathrm{mg} / \mathrm{kg}$ produced an overall significant increase in the number of fecal boli [treatment, $F(1,84)=26.2, p<.001]$, the magnitude of which was not significantly different among the groups (groups $\times$ treatment interaction, $p>.70$ ). However, as shown in Table 1, a significant difference was observed among the three groups treated with saline $[F(2,44)=$ $6.5, p<.001]$; both MB-lesioned and alcohol-treated animals exhibited less fecal boli than did controls $(p<$ .001 and $p<.01$, respectively). Note that within the MB group, $\beta-\mathrm{CCM}$ at $1.0 \mathrm{mg} / \mathrm{kg}$ did not produce any further increase in fecal boli relative to $\beta$-CCM at $(0.5 \mathrm{mg} / \mathrm{kg})$. 
Table 1

Measures of Activity and Fecal Boli in the Open Field For Saline and $\beta$-CCM Treatments in the Control, MB-Lesioned, and Alcohol-Treated Groups

\begin{tabular}{|c|c|c|c|c|c|c|c|c|c|c|c|c|}
\hline \multirow[b]{3}{*}{ Group } & \multicolumn{6}{|c|}{ Locomotor Activity } & \multicolumn{6}{|c|}{ Fecal Boli } \\
\hline & \multicolumn{2}{|c|}{ Saline } & \multicolumn{2}{|c|}{$\beta-\mathrm{CCM} 0.5 \mathrm{mg} / \mathrm{kg}$} & \multicolumn{2}{|c|}{$\beta-\mathrm{CCM} 1 \mathrm{mg} / \mathrm{kg}$} & \multicolumn{2}{|c|}{ Saline } & \multicolumn{2}{|c|}{$\beta-C C M 0.5 \mathrm{mg} / \mathrm{kg}$} & \multicolumn{2}{|c|}{$\beta-\mathrm{CCM} 1 \mathrm{mg} / \mathrm{kg}$} \\
\hline & $M$ & $\overline{S E M}$ & $M$ & SEM & $M$ & $S E M$ & $M$ & $S E M$ & $M$ & $S E M$ & $M$ & $S E M$ \\
\hline Control & 67.4 & 8.8 & 48.7 & 11.4 & 29.4 & $7.0^{*}$ & 5.32 & 0.52 & 7.71 & 0.57 & 9.05 & $1.49^{*}$ \\
\hline MB & 98.0 & 18.4 & 37.8 & $6.0^{*}$ & 40.2 & $5.5^{*}$ & 1.00 & $0.53 \#$ & 3.94 & $0.73 * \S$ & 3.21 & $0.45^{*} \|$ \\
\hline Alcohol & 88.3 & 11.2 & 23.3 & $2.4 \ddagger$ & not done & 2.30 & $0.83 \|$ & 5.82 & $0.55 \dagger$ & not done & & \\
\hline
\end{tabular}

*Significantly different from saline condition (same group), $p<.05$. †Significantly different from saline condition (same group), $p<.01$. \$Significantly different from saline condition (same group), $p<.001$. \$Significantly different from controls (same treatment), $p<.05$. ||Significantly different from controls (same treatment), $p<.01$. \#Significantly different from controls (same treatment), $p<.001$.

Elevated plus maze. Data are summarized in Table 2. Two-factor ANOVAs showed that changes in both entry ratio and time ratio following $\beta-\mathrm{CCM}$ at $0.5 \mathrm{mg} / \mathrm{kg}$ were significantly different among groups $[F \mathrm{~s}(2,84)=4.06$ and $9.3, p=.02$ and $p<.001$, respectively]. In particular, even though MB-lesioned animals displayed a significant increase in latency ratio relative to controls (saline condition, $p<.01$ ), they behaved as controls did under $\beta$-CCM (at both doses; see Table 2), with $\beta$-CCM at $1.0 \mathrm{mg} / \mathrm{kg}$ producing a decrease of similar magnitude to that of $\beta-C C M$ at $(0.5 \mathrm{mg} / \mathrm{kg})$.

Conclusion. As is to be expected from its known behavioral effects, $\beta$-CCM at 0.5 and $1.0 \mathrm{mg} / \mathrm{kg}$ induced, in normal mice, anxiogenic reactions in both the elevated plus maze and the open field. Chronic alcohol administration and $\mathrm{MB}$ lesion reduced anxiogenic reactions in both the elevated plus maze and the open field, even though results were significantly different from controls only in the open-field task.

\section{Memory}

A two-factor ANOVA showed that the effects of $\beta$-CCM at $0.5 \mathrm{mg} / \mathrm{kg}$ on mean SA rates over the whole session (six trials) was significantly different among groups [groups $\times$ treatment interaction, $F(2,84)=$ $7.33, p<.01]$. This is mainly because the impairment of SA produced by alcohol (from $74.3 \%$ for controls to $54.0 \%$ for alcohol-saline group; $p<.01$ ) was significantly reduced by $\beta$-CCM (from $54 \%$ to $81.8 \% ; p<$ .001 ), whereas the impairment of SA produced by MB lesion (from $74.3 \%$ to $57.8 \% ; p<.01$ ) was not $(57.8 \%$ and $52.2 \%$, respectively, for the saline and $\beta$-CCM- treated MB mice). In controls, $\beta-\mathrm{CCM}$ at $0.5 \mathrm{mg} / \mathrm{kg}$ induced a nonsignificant increase of SA rate (from $74.3 \%$ to $85.7 \% ; p>.10$ ). Direct comparison between SA rates in the $\mathrm{MB}$ and alcohol groups confirms the differential effect of $\beta$-CCM at $0.5 \mathrm{mg} / \mathrm{kg}$ [group $\times$ treatment interaction, $F(1,44)=15.5, p<.001]$. In MB-lesioned mice, however, increasing the dose of $\beta$-CCM from 0.5 to $1.0 \mathrm{mg} / \mathrm{kg}$ resulted in a significant improvement of the lesion-induced SA deficit $[F(2,43)=19.5, p<.001]$, the magnitude of which (from $57.8 \%$ to $80 \% ; p<.01$ ) was similar to the one observed with the lower dose $(0.5 \mathrm{mg} / \mathrm{kg}$ ) in the alcohol group (from $54 \%$ to $81.8 \%$ ). In controls, $\beta$-CCM at $1.0 \mathrm{mg} / \mathrm{Kg}$ slowed down the $\mathrm{SA}$ rate (from $74.3 \%$ to $67.6 \%$ ); however, this effect was not significant $(F<1.0)$.

Another point that deserves consideration is that both the impairment of SA produced by MB lesion or alcohol consumption and their reversal by $\beta$-CCM were trialdependent. Specifically, an ANOVA showed a significant group ( 8 groups $) \times$ trial $(6$ trials $)$ interaction $[F(28,488)$ $=1.64, p=.02]$. Indeed, trial-by-trial between-groups comparisons did not reveal any significant differences in SA rates on each of the first two trials (Trials 2 and 3, $p>.40)$ and on Trial $4(p>.20)$; conversely, highly significant between-groups differences were observed on each of the two last trials (Trials 5 and $6, p<.001$ ). Thus, as shown in Table 3, saline-treated animals in both the $\mathrm{MB}$ and alcohol groups were dramatically impaired relative to controls on the last two trials (Trials 5-6, $p<$ .01 , for each comparison), but they performed normally on the two first ones (Trials 2-3) [group $\times$ trial interaction, $F(2,45)=7.6, p<.01]$. Moreover, the effect of

Table 2

Measures of Latency and Entry Ratios in the Elevated Plus Maze for Saline and $\beta$-CCM Treatments in the Control, MB-Lesioned, and Alcohol-Treated Groups

\begin{tabular}{|c|c|c|c|c|c|c|c|c|c|c|c|c|}
\hline \multirow[b]{3}{*}{ Group } & \multicolumn{6}{|c|}{ Latency Ratio } & \multicolumn{6}{|c|}{ Entry Ratio } \\
\hline & \multicolumn{2}{|c|}{ Saline } & \multicolumn{2}{|c|}{$\beta-\mathrm{CCM} 0.5 \mathrm{mg} / \mathrm{kg}$} & \multicolumn{2}{|c|}{$\beta-\mathrm{CCM} 1 \mathrm{mg} / \mathrm{kg}$} & \multicolumn{2}{|c|}{ Saline } & \multicolumn{2}{|c|}{$\beta-$-CM $0.5 \mathrm{mg} / \mathrm{kg}$} & \multicolumn{2}{|c|}{$\beta-\mathrm{CCM} 1 \mathrm{mg} / \mathrm{kg}$} \\
\hline & $M$ & $\overline{S E M}$ & $M$ & $S E M$ & $M$ & $S E M$ & $\vec{M}$ & $\overline{S E M}$ & $M$ & $S E M$ & $M$ & SEM \\
\hline Control & 134 & ( & 0.146 & $0.016^{*}$ & 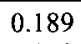 & 0.02 & 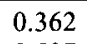 & 0. & 0.1 & $0.015 \dagger$ & 0.189 & $0.020^{*}$ \\
\hline MB & c & $+\S$ & 0 & $0 . c$ & 0.093 & $0.021 \mp 8$ & 0.5 & 0.054 & 0.171 & $0.029 \ddagger$ & 0.183 & 0.028 \\
\hline Alcohol & 0.445 & $0.063^{\circ}$ & 0.303 & 0.067 & \multicolumn{2}{|c|}{ not done } & 0.507 & 0.041 & 0.339 & 0.018 & \multicolumn{2}{|c|}{ not done } \\
\hline
\end{tabular}

*Significantly different from saline condition (same group), $p<.05$. †Significantly different from saline condition (same group), $p<.01$. †Significantly different from saline condition (same group), $p<.001$. \$Significantly different from controls (same treatment), $p<.01$. 
Table 3

Mean Percent (and SEM) SA Rates in the Control, MB-Lesioned, and Alcohol-Treated Groups as a Function of Trials (Trials 2 and 3 vs. Trials 5 and 6 ) and Treatment (Saline and $\beta$-CCM)

\begin{tabular}{|c|c|c|c|c|c|c|c|c|c|c|c|c|}
\hline \multirow[b]{3}{*}{ Treatment } & \multicolumn{6}{|c|}{ Trials 2 and 3} & \multicolumn{6}{|c|}{ Trials 5 and 6} \\
\hline & \multicolumn{2}{|c|}{ Saline } & \multicolumn{2}{|c|}{$\beta-\mathrm{CCM} 0.5 \mathrm{mg} / \mathrm{kg}$} & \multicolumn{2}{|c|}{$\beta-\mathrm{CCM} 1 \mathrm{mg} / \mathrm{kg}$} & \multicolumn{2}{|c|}{ Saline } & \multicolumn{2}{|c|}{$\beta-\mathrm{CCM} 0.5 \mathrm{mg} / \mathrm{kg}$} & \multicolumn{2}{|c|}{$\beta \cdot \mathrm{CCM} 1 \mathrm{mg} / \mathrm{kg}$} \\
\hline & $M \%$ & $S E M$ & $M \%$ & $S E M$ & $M \%$ & $S E M$ & $M \%$ & $S E M$ & $M \%$ & $S E M$ & $M \%$ & $S E M$ \\
\hline Control & 76.8 & 4.8 & 75.0 & 6.9 & 71.4 & 6.5 & 80.4 & 5.9 & 92.9 & 4.9 & 69.1 & 8.1 \\
\hline MB & 83.3 & 8.3 & 63. & 7.9 & 71.1 & 7.0 & 44.4 & $10.0^{\dagger}$ & 47.2 & $9.5 \S$ & 81.6 & $5.7^{*}$ \\
\hline Alcohol & 90.0 & 6.7 & 77.3 & 7.9 & \multicolumn{2}{|c|}{ not done } & 30.0 & $8.2 \S$ & 95.5 & $4.6 \dagger$ & \multicolumn{2}{|c|}{ not done } \\
\hline
\end{tabular}

* Significantly different from saline condition (same group, same trials), $p<.01$. †Significantly different from saline condition (same group, same trials), $p<.001$. †Significantly different from controls (same treatment), $p<.01 . \S$ Significantly different from controls (same treatment), $p<.001$.

$\beta$-CCM at $0.5 \mathrm{mg} / \mathrm{kg}$ came out as an interaction with the groups ( 3 groups) and with the blocks of trials $[F(2,84)=$ $3.92, p=.024]$.

Finally, the effects of $\beta$-CCM in MB-lesioned mice, relative to controls, depended both on the dose administered and on the block of trials $[F(2,103)=3.42, p=$ $.036]$. Thus, $\beta$-CCM at $1.0 \mathrm{mg} / \mathrm{kg}$ (MB-lesioned mice) produced a trial-dependent improvement of SA rates that resembles the one produced by the lower dose $(0.5 \mathrm{mg} / \mathrm{kg})$ in the alcohol group; specifically, in both cases, administration of $\beta$-CCM resulted in a significant improvement of SA rates on the last two trials, whereas no effects at all were observed on the first two.

Conclusion. The decrease of alternation rates observed for both MB-lesioned and alcohol-treated mice is totally alleviated by the injection of $\beta$-CCM. The effects of $\beta$-CCM depended on the treatment, the dose administered, and the place of the trials in the series. Specifically, $\beta$-CCM at $0.5 \mathrm{mg} / \mathrm{kg}$ was sufficient to improve performance in controls and alcohol-treated mice, but a higher dose $(1.0 \mathrm{mg} / \mathrm{kg})$ was required for the same effect in MB-treated subjects. In all cases, both impairment and improvement of SA rates as a function of the groups were observed on the two last trials of the series (Trials 5 and 6) but not on Trials 2 and 3.

\section{DISCUSSION}

The present study was aimed at assessing whether $\beta$-CCM, a drug known to increase anxiety and to improve memory in normal subjects, might alleviate or attenuate the memory deficits resulting from either a chronic alcohol treatment or experimental lesion of the mammillary bodies. The results show that both MB lesions and chronic alcohol consumption produce a memory impairment in the sequential alternation task, as well as a reduction of anxiogenic reactions in the open field and the elevated plus maze. The administration of $\beta$-CCM in the subjects totally alleviated the sequential alternation deficit and increased anxiogenic reactions in the open field and the elevated plus maze.

The performances in the SA task resulting from the treatments and drug administrations cannot be ascribed to proactive effects of the open-field and elevated plus maze tasks. First, we replicated the main effects of $\beta$-CCM described here in alcohol-treated subjects and controls using mice that had not been submitted to previous exposure to tests of emotionality (Bontempi, 1993; Bontempi, Béracochéa, Destrade, \& Jaffard, 1992). Second, the deficits observed in chronic ethanol administration and MB saline-treated mice reported in this study were previously observed in subjects run under a different experimental schedule (Béracochéa \& Jaffard, 1985, 1987). Thus, the findings reported here appear to be independent of the general procedure used.

In saline-treated subjects, both chronic ethanol treatment and MB lesions induced an impairment of SA rates (mainly observed on the last trials of the series but not on the first two), relative to controls. In parallel, alcoholtreated and MB-lesioned mice exhibited a reduction of anxiety-like reactions in the open field and the elevated plus maze. These data confirm previous findings showing that these treatments induced in the sequential SA task an exaggerated vulnerability to accumulative interference, as well as emotional disorders, relative to normal mice (Béracochéa \& Jaffard, 1985, 1987, 1990; Béracochéa \& Krazem, 1991).

The administration of $\beta-\mathrm{CCM}$ at doses increasing anxiety-like reactions induced an improvement of alternation rates (relative to those of controls) observed on the last trials of the series but not on the first trials. Thus, it can be proposed that $\beta$-CCM administration improves SA rates by reducing the vulnerability to accumulative proactive interference. Such an interpretation agrees with other reports suggesting that the memoryenhancing effects of benzodiazepine receptor inverse agonists could be mediated either by improved retention or by resistance to interference during the delay period (Moran, Kane, \& Moser, 1992). The alleviation of the deficits in the alcohol-treated group is congruent with another report showing that the memory deficits resulting from chronic ethanol administration in rats are reversed by the administration of ZK 93426, a compound classified as either antagonist or selective inverse agonist of the BDZ receptor (Hodges, Trasher, \& Gray, 1989; Sarter, 1990).

The memory-enhancing effects produced by $\beta$-CCM administration fit well with data showing that compounds acting directly or indirectly on GABAergic cells may either improve or impair working memory (Chrobak \& Napier, 1992; Stackman \& Walsh, 1992). Such effects are linked with the modulation that GABAergic 
cells exert on various individual neurotransmiters systems--namely, but not exclusively, the cholinergic system (Decker \& McGaugh, 1991). However, without underestimating the general effects of systemic administrations, the fact that, in MB-lesioned mice, a higher dose is required to enhance memory relative to alcoholtreated subjects (which exhibit only moderate MB damage; see Béracochéa \& Jaffard, 1987; Lescaudron et al., 1984) suggests that the memory-enhancing effects of $\beta$-CCM depend on the amount of damage to the MB and, therefore, that the memory-facilitating effects of the drug are mediated, at least in part, by the MB activity. This hypothesis has gained support from a recent study performed in our laboratory, using the 2-deoxyglucose (2-DG) technique to assess brain metabolic activity in alcohol-treated mice. We showed that 12 -month alcoholtreated mice exhibited deficits in the sequential alternation task together with a significant reduction of the metabolic activity into the $\mathrm{MB}$, relative to controls. In contrast, the administration of $\beta$-CCM at $0.5 \mathrm{mg} / \mathrm{kg}$ suppressed the memory deficits of alcohol-treated subjects and resulted, concomitantly, in an increase of 2-deoxyglucose labeling mainly in the mammillary nuclei and the cingulate cortex (Bontempi, 1993; Bontempi et al., 1992). This study provided two significant findings. First, these data confirmed our previous anatomical quantitative analysis (Lescaudron et al., 1984) showing that the MB nuclei of alcohol-treated mice are particularly vulnerable to the effects of ethanol. Thus, the MB damage, which may vary in magnitude and extent from one study to another, are nevertheless reproducible and constant effects of the long-term alcohol administration throughout studies, at least in Balb/c mice (Béracochéa et al., 1987; Bontempi et al., 1993; Lescaudron et al., 1984). Second, the enhancement of the 2-DG metabolic activity produced by the $\beta$-CCM administration in alcohol-treated subjects corroborates data showing that the MB nuclei are highly sensitive to $\mathrm{BDZ}$ administration. More specifically, BDZ-induced metabolic changes have already been observed in the MB nuclei following an i.p. administration of diazepam in the rat (Ableitner, Wüster, \& Herz, 1985), a result that is not surprising given the particularly high densities of BDZ receptors and GABAergic cells in the MB (Eymin et al., 1992; Gonzalo-Ruiz, Sanz-Anquela, \& Spencer, 1993).

It has been shown that the administration of BDZ might simulate or model the form of memory dysfunctions that are expressed in typical amnesic patients as well as in patients exhibiting frontal dysfunction (Danion et al., 1993). However, if it is acknowledged that BDZ impairs acquisition processes, the effects of the drug on retrieval processes are controversial (Béracochéa, 1992). Whether or not, in the present study, the effects of $\beta$-CCM were exclusively due to a retrieval enhancement was not determined. However, given the nature of the alcoholinduced amnesia that, in our experimental conditions, resulted from a selective retrieval deficit (see Béracochéa $\&$ Jaffard, 1985, 1987), it may be suggested that $\beta$-CCM may be effective in the treatment of amnesia resulting from an impairment of retrieval processes (i.e., accessibility to stored memory contents). However, since the memory-enhancing effects of the drug are observed at doses having anxiogenic properties, further studies are required to determine if, as demonstrated in normal subjects (Chapouthier et al., 1991; McNamara \& Skelton, 1993 ), lower doses of $\beta$-CCM could improve memory in alcohol-treated subjects via a mechanism that is independent of anxiety.

\section{REFERENCES}

Ableitner, A., WÜster, M., \& Herz, A. (1985). Specific changes in local cerebral glucose utilization in the rat brain induced by acute and chronic diazepam. Brain Research, 359, 49-56.

BÉrACOCHÉA, D. J. (1992). Are the effects of benzodiazepines limited to acquisition processes? Cahier de Psychologie Cognitive/European Bulletin of Cognitive Psychology, 12, 459-466.

BÉRACOCHÉA, D. J., \& JAFFARD, R. (1985). Memory deficits subsequent to chronic consumption of alcohol in mice: An analysis based on spontaneous alternation behavior. Behavioral Brain Research, $15,15-25$.

BÉRACOCHÉA, D. J., \& J JFFARD, R. (1987). Impairment of spontaneous alternation behavior in sequential test procedures following mammillary body lesions in mice: Evidence for time-dependent interference-related memory deficits. Behavioral Neuroscience, 101, 187-197.

BÉRACOCHÉA, D. J., \& JAFFARD, R. (1990). Effects of ibotenic lesions of the mammillary bodies on spontaneous and rewarded spatial alternation in mice. Journal of Cognitive Neuroscience, 2, 133-140.

BÉRACOCHÉA, D. J., \& KRAZEM, A. (1991). Effects of mammillary bodies and mediodorsal thalamic lesions on elevated plus maze exploration. NeuroReport, 2, 793-796.

BÉraCochÉA, D. J., Lescaudron, L., TAKo, A., Verna, A., \& JAFFard, R. (1987). Build-up and release from proactive interference during chronic ethanol consumption in mice: A behavioral and neuroanatomical analysis. Behavioral Brain Research, 25, 63-74.

BONTEMPI, B. (1993). Modifications du métabolisme cérébral induites par les activités mnésiques chez la souris: Implications fonctionnelles dans les processus de consolidation et de restitution. Doctoral thesis, University of Bordeaux.

Bontempi, B., Béracochéa, D. J., Destrade, C., \& Jaffard, R. (1992). Memory deficits and associated decreases of cerebral 2-DG labelling induced by chronic ethanol consumption in mice: Reversal by $\boldsymbol{\beta}$-carbeline-3-carboxylate administration. Society for Neuroscience Abstracts, 18, 1425.

Chapouthier, G., Rafalli-Sebille, M.-J., Venault, P., Simiand, J., \& DoDD, R. H. (1991). Comparison between the effects of the benzodiazepine receptor ligands methyl beta-carboline-3-carboxylate and diazepam in two learning situations in mice. Psychobiology, 19, 58-63.

ChrobaK, J. J., \& Napier, T. C. (1992). Delayed non-match-to-sample performance in the radial arm maze: Effects of dopaminergic and gabaergic agents. Psychopharmacology, 108, 72-78.

CoOper, S. (1987). Bidirectional changes in the consumption of food produced by $\beta$-carbolines. Brain Research Bulletin, 19, 347-358.

Danion, J. M., Weingartner, H., File, S. E., JafFard, R., Sunderland, T., Tulving, E., \& Warburton, D. M. (1993). Pharmacology of human memory and cognition: Illustrations from the effects of benzodiazepines and cholinergic drugs. Journal of Psychopharmacology, 7, 371-377.

Decker, M. W., \& MC Gaugh, J. L. (1991). The role of interactions between the cholinergic system and other neuromodulatory systems in learning and memory. Synapse, 7, 151-168.

DennenberG, V. H. (1969). Open-field behavior in the rat: What does it mean? In E. Tobach (Ed.), Experimental approaches to the study of behavior (Annals of the New York Academy of Sciences, Vol. 159, pp. 852-859). New York: New York Academy of Sciences.

Eymin, C., Koll, N., \& Laurent, B. (1992). Central benzodiazepinebinding sites in human cerebral structures associated with memory processes. Dementia, 3, 232-238. 
File, S. E., \& BaLdwin, H. A. (1987). Effects of $\beta$-carbolines in animal models of anxiety. Brain Research Bulletin, 19, 293-299.

Gonzalo-Ruiz, A., Sanz-Anquela, J. M., \& Spencer, R. F. (1993). Immunohistochemical localization of GABA in the mammillary complex of the rat. Neuroscience, 54, 143-156.

GRANT, D. S. (1981). Intertrial interference in rat short-term memory. Journal of Experimental Psychology, 7, 217-227.

Hodges, H., Trasher, S., \& Gray, J. A. (1989). Improved radial maze performance induced by the benzodiazepine antagonist ZK 93426 in lesioned and alcohol-treated rats. Behavioural Pharmacology, 1, 45-55.

Hunkeler, W. H., Mohler, L., Pieri, L., Polc, P., Bonetti, E. P., Cumin, R., Schaffner, R., \& Haefely, W. (1981), Selective antagonists of benzodiazepines. Nature, 290, 564-569.

Kataoka, Y., Shibata, K., Gomita, Y., \& Ueki, S. (1982). Mammillary body is a potential site of antianxiety action of benzodiazepines. Brain Research, 241, 374-377.

Lescaudron, L., Béracochéa, D. J., Verna, A., \& Jaffard, R. (1984). Chronic ethanol consumption induces neuronal loss in mammillary bodies of the mouse: A quantitative analysis. Neuroscience Letters, 50, 151-155.

LHERMITTE, F., \& SigNoRET, J. L. (1972). Analyse neuropsychologique et differentiation des syndromes amnésiques. Revue Neurologique, 126, 161-178.

LisTER, R. G. (1987). The use of a plus-maze to measure anxiety in the mouse. Psychopharmacology, 92, 180-185.

MCNamaRA, R. K., \& Skelton, R. W. (1993). Benzodiazepine receptor antagonists flumazenil and CGS 8216 and inverse-agonist $\beta$-CCM enhance spatial learning in the rat: Dissociation from anxiogenic actions. Psychobiology, 21, 101-108.

Moran, P. M., Kane, J. M., \& Moser, P. C. (1992). Enhancement of working memory performance in the rat by MDL 26,479 , a novel compound with activity at the GABA-A receptor complex. Brain Research, 569, 156-158.

O'KeEFE, J. (1979). Hippocampal function: Does the working memory hypothesis work? Should we retire the cognitive map theory? Behavioral \& Brain Sciences, 2, 339-343.

Pellow, S., Chopin, P., File, S. E., \& Briley, M. (1985). Validation of open:closed arm entries in an elevated plus-maze as a measure of anxiety in the rat. Journal of Neuroscience Methods, 14, 149-167.

RoBerts, A. R., \& DALE, R. H. (1981). Remembrance of places lasts: Proactive inhibition and patterns of choice in rat spatial memory. Learning \& Motivation, 12, 261-281.

SARTER, M. (1990). Elevation of local cerebral glucose utilization by the $\beta$-carboline ZK 93 426. European Journal of Pharmacology, 177, 155-162.

Stackman, R. W., \& Walsh, T. J. (1992). Chlordiazepoxide-induced working memory impairments: Site specificity and reversal by Flumazenil (RO15-1788). Behavioral \& Neural Biology, 57, 233-243.

Venault, P., Chapouthier, G., Prado De Carvalho, L., Simiand, J., Morre, M., DoDD, R. H., \& Rossier, J. (1986). Benzodiazepine impairs and $\beta$-carboline enhances performance in learning and memory tasks. Nature, 321, 864-866.

(Manuscript received January 5, 1994; revision accepted for publication September 21, 1994.) 